\title{
Use of antimicrobials for contamination control during ethanolic fermentation
}

\section{Utilização de antimicrobianos para o controle da contaminação durante a fermentação etanólica}

\section{Leonardo Lucas MADALENO ${ }^{1}$; Guilherme Deomedesse MINARI²; Flávia Roberta de ANNUNZIO³; Márcio Roberto de CARVALHO ${ }^{4}$; Gino Roda BOSSA JÚNIOR ${ }^{5}$; Deise Chaves SALES ${ }^{6}$; Mariana Carina FRIGIERI ${ }^{7}$}

${ }^{1}$ Autor para correspondência" - Doutor em Agronomia (Produção Vegetal) - Faculdade de Tecnologia de Jaboticabal/Fatec
Nilo de Stéfani. Av. Eduardo Zambianchi, 31. CEP: $14883-130$ - Vila Industrial - Jaboticabal - SP, leoagro@gmail.com
${ }^{2}$ Mestrando em Microbiologia Agropecuária - Faculdade de Ciências Agrárias e Veterinárias - FCAV/Unesp Jaboticabal.
Via de Acesso Prof. Paulo Donato Castellane s/n. CEP: 14884-900 - Jaboticabal, SP, gdminari@gmail.com
${ }^{3}$ Tecnólogo em Biocombustíveis - Faculdade de Tecnologia de Jaboticabal/Fatec Nilo de Stéfani. Av. Eduardo
Zambianchi, 31. CEP: 14883-130 - Vila Industrial - Jaboticabal - SP, flaviannunzio@hotmail.com
${ }^{4}$ Tecnólogo em Biocombustíveis - Faculdade de Tecnologia de Jaboticabal/Fatec Nilo de Stéfani. Av. Eduardo
Zambianchi, 31. CEP: 14883-130 - Vila Industrial - Jaboticabal - SP, marciorc2@hotmail.com
${ }^{5}$ Tecnólogo em Biocombustíveis - Faculdade de Tecnologia de Jaboticabal/Fatec Nilo de Stéfani. Av. Eduardo
Zambianchi, 31. CEP: 14883-130 - Vila Industrial - Jaboticabal - SP, gino_junior@hotmail.com
${ }^{6}$ Tecnólogo em Biocombustíveis - Faculdade de Tecnologia de Jaboticabal/Fatec Nilo de Stéfani. Av. Eduardo
Zambianchi, 31. CEP: 14883-130 - Vila Industrial - Jaboticabal - SP, deise_mirai@hotmail.com
${ }^{7}$ Doutora em Biotecnologia - Faculdade de Tecnologia de Jaboticabal/Fatec Nilo de Stéfani. Av. Eduardo Zambianchi, 31.
CEP: $14883-130$ - Vila Industrial - Jaboticabal - SP, marifrigieri@gmail.com

Recebido em: 14-01-2015; Aceito em: 08-01-2016

\begin{abstract}
This study aim to compare the action of antimicrobials: hop extract, oregano essential oil (OEO) and chlorine dioxide during the fermentation process. For this purpose, three studies have been conducted. In the first two studies, control treatment, Kamoran $\AA\left(3 \mathrm{mg} \mathrm{L}^{-1}\right)$, oregano oil $(0.5 \%)$ and hop extract $\left(10 \mathrm{mg} \mathrm{L}^{-1}\right)$ were used. In the third experiment, hop extract was replaced by chlorine dioxide $\left(0.15 \mathrm{mg} \mathrm{L}^{-1}\right)$ and oregano concentration was also increased to $1 \%$. The quality of mash and wine obtained was evaluated. During the fermentation process, feasibility analyses and initial and final contamination analyses were carried out. It was verified that OEO has no antimicrobial effect, on the other hand, it has properties that can be antifoaming and/or dispersant. Hop extract reduced the final contamination of the fermentation of the mash of sugarcane juice and molasses. The antimicrobial treatments used did not reduce the viability of yeast cells.
\end{abstract}

Additional keywords: biocides; chlorine dioxide; hop; Kamoran®; oregano oil.

\section{Resumo}

O presente trabalho procurou comparar a ação dos antimicrobianos: extrato de lúpulo, óleo essencial de orégano (OEO) e dióxido de cloro, durante o processo fermentativo. Para tanto, três estudos foram conduzidos. Nos dois primeiros estudos, foi utilizado o tratamento-testemunha, Kamoran $\AA\left(3 \mathrm{mg} \mathrm{L}^{-1}\right)$, óleo de orégano $(0,5 \%)$ e extrato de lúpulo (10 $\left.\mathrm{mg} \mathrm{L}^{-1}\right)$. No terceiro experimento, o extrato de lúpulo foi substituído pelo dióxido de cloro $(0,15 \mathrm{mg}$ $\mathrm{L}^{-1}$ ) e houve também aumento da concentração de orégano para $1 \%$. Foram avaliadas as qualidades do mosto e do vinho obtido. Durante o processo fermentativo, foram realizadas análises de viabilidade e de contaminação inicial e final. Foi possível verificar que o OEO não possuiu efeito antimicrobiano; por outro lado, apresentou propriedades que podem ser antiespumante e/ou dispersante. O lúpulo reduziu a contaminação final da fermentação do mosto de caldo de cana e de melaço. Os tratamentos antimicrobianos utilizados não reduziram a viabilidade das células de leveduras.

Palavras-chave adicionais: biocidas; dióxido de cloro; Kamoran®; lúpulo; óleo de orégano.

\section{Introduction}

In Brazil, the most used raw material for ethanol production comes from sugarcane (Saccharum spp.). Sugarcane juice and molasses, residue from sugar production, are the main materials used in the mash preparation for ethanolic fermentation. The biochemical process is performed by yeasts (Saccharomyces cerevisiae), which transform mash sugars coming from the juice or molasses into ethanol (Dashko et al., 2014). Then, the wine obtained is subjected to the distillation process, in which hydrated ethanol (used in flexfuel vehicles) and anhydrous (used in mixture with gasoline) are produced (Chum et al., 2014).

Prior to distillation, part of the yeasts are 
separated from the wine and subjected to treatment for recovery and reuse in a new fermentation process and this procedure is performed over the entire crop. One of the actions in the treatment is the dilution of the yeast, which aims to reduce the effects of substances, like ethanol itself, that cause toxicity to the yeast. Another action is the $\mathrm{pH}$ reduction to 2.5 using sulfuric acid in an attempt to reduce the main fermentation problem, which is bacterial contamination (Basso et al., 2014).

Contamination may come from the quality of the raw material, the dilution water used in the mash and the industry itself through pipes and pieces of equipment exposed to microorganisms (Oliveira et al., 2013). The presence of unwanted microorganisms can affect the process through consumption of sugar, decrease of yeast cell viability due to the toxins secreted by bacteria in the medium, yeast flocculation, which causes loss of yeast cells at the bottom of the vat or in the centrifuge, and decrease in industrial yield (Muthaiyan et al., 2011). Furthermore, there is the formation of gums and biofilms, which increase juice viscosity and cause operational problems in the plant (Skinner-Neme et al., 2007), reducing the efficiency of ethanol production.

When contamination values exceed the acceptable levels and the usual yeast treatment is not sufficient to the control, industry uses antimicrobials to the combat, such as antibiotics (Muthaiyan et al., 2011). Many, as Kamoran $B$, are employed with relative level of success in reducing contamination (Leite et al., 2013). However, this method leaves residues in yeasts discarded from the process, which go through the drying process, and can no longer be used as a supplement in animal feed (Olmstead, 2012). Dry yeasts, which had antibiotic usage history, should be incinerated and the plant fails to obtain economic gains with this byproduct.

In this context, the study of other control methods in the treatment of yeast arises, which are antimicrobials popularly known as biocides, which are natural substances used as an alternative to antibiotics. As an example, hop extract, propolis, grapefruit and others that have been studied and show relative efficiency in contamination control. Hop extract seems to be, so far, the most efficient among the possibilities (Caetano \& Madaleno, 2011).

A promising biocide could be oregano oil (OEO), which has a recognized action on bacteria (Silva et al., 2010). During fermentation, used in optimal dosage, it could favor bacteria control and preserve yeast. OEO contains mostly carvacrol, a phenolic compound known for its anti-infective properties of broad spectrum, which makes it a very effective antibacterial agent (Naturoils, 2014).

Another contamination control method is the use of chemicals that have known effects on contaminants, such as chlorine dioxide. This substance is a strong oxidant, which has many applications, for example, in gaseous form for bacterial decontamination, and can also be applied to sewage as a disinfectant and inhibitor of algae growth (Lapolli, 2005) and is currently being used by some plants, seeking to reduce contamination.

In order to have adequate antimicrobial effect, the agent mash control bacteria and prevent damage to yeast. Most studies focuses on the use of biocides in the treatment of yeast in replacement to antibiotics. However, the study of the application of the methods during fermentation has been little explored. The benefit of the control during the fermentation process would help to reduce the volume of contaminants to the yeast treatment and, thereby, increase ethanol production.

This paper aimed to compare the action of the antimicrobials: hop extract, oregano oil and chlorine dioxide during the fermentation process in mash of sugarcane juice and molasses.

\section{Material and methods}

The experiments were conducted in the laboratories on the campus of FATEC Nilo De Stéfani, Jaboticabal-SP. The first study was conducted with the fermentation of the mash prepared from molasses and the second study, using the mash of sugarcane juice, both held in October, during the 2012/2013 harvest. In the third test, we used again mash of molasses, collected in May during the 2013/2014 harvest. All raw materials for mash preparation were obtained in sugar mills of the region of Jaboticabal-SP.

The study was conducted in randomized blocks because in the used shaker (place where the simulation of the fermentation process was performed, with shake and temperature control) there were four spaces, which allowed putting only four erlenmeyers corresponding to the four treatments used in each study. Since there is variation in the quality of raw material used for preparing the mash for each day, the blocks experimental design were used to mitigate the random effect (day of fermentation) and highlight the treatments used.

The design used for all tests was randomized blocks with 5 repetitions. Four treatments were used for the study of antimicrobials. In the first two studies (juice and molasses from the 2012/2013 harvest), control treatment, Kamoranß $\left(3 \mathrm{mg} \mathrm{L}^{-1}\right.$, according to Química Real (2014)), OEO extracted from leaves (0.5\%, according to Silva (2010)) from brand Mundo dos óleos $\AA$ (Mundo dos óleos, 2014) and hop (10 $\mathrm{mg} \mathrm{L}^{-1}$, according to Química Real (2014)) were used. In the third experiment, hop extract was replaced by chlorine dioxide $\left(0.15 \mathrm{mg} \mathrm{L}^{-1}\right)$ and oregano concentration was also increased to $1 \%$.

For the experiments, it was necessary to dilute molasses and sugarcane juice to $14^{\circ}$ Brix. Mash $\mathrm{pH}$ was adjusted to 4.5 by adding sulfuric acid $(5 \mathrm{~N})$. Then, quality analyses of the mash were performed by determination of total acidity (CTC, 2005) and TRS (total reducing sugars), according to Lane \& Eynon (1934). 
For all experiments, compressed yeast (Saccharomyces cerevisiae) in the proportion of $30 \mathrm{~g} \mathrm{~L}$ ${ }^{1}$ was used. In pre-fermentation, yeast was distributed into four beakers, each containing $50 \mathrm{~mL}$ of glucose solution $1 \%$, remaining for an hour, to prepare the yeast. Then, each was subjected to centrifugation (centrifuge Sppencer $80-2 b$ ) at 3000 rpm for five minutes. Then, supernatant was removed and yeasts were transferred to erlenmeyer (1L), with washing of the centrifuge tubes using $100 \mathrm{~mL}$ of mash.

The following feeds, with $100 \mathrm{~mL}$ of mash, were timed every 15 minutes until reaching the total volume of $500 \mathrm{~mL}$. Biocide treatments were added between the penultimate and the last feed. After fifteen minutes from the last feed, samples were taken for feasibility and initial contamination analysis. Then, the containers were taken to benchtop shaking incubator (Shaker CT-712, Cienter). For tests of the 2012/2013 harvest, the incubation temperature was $36^{\circ} \mathrm{C}$ and for the fermentation conducted in May 2013, the temperature was $32^{\circ} \mathrm{C}$.

To carry out the fermentation process, feeds with mash were made intermittently, so that yeasts adaptated to the concentration of 14 Brix and produced fewer side compounds. Then, antimicrobial treatments were placed before the last feed in an attempt to simulate the conditions that would be found in the plant, in which the continuous vat feed is made and the biocide could be added to the end of the feed to combat bacteria during the fermentation process.

For fermentation using the raw sugarcane juice to be completed, measurements of soluble solids concentration have been performed (manual densimeter - saccharimeter), adopting final value lower than $1{ }^{\circ}$ Brix, also accounting the total process time. To the end of the fermentation experiment using molasses as raw material, soluble solids concentration lower than $4^{\circ}$ Brix was adopted as final. Then, wine samples (obtained through fermentation process) were collected to verify the viability and final contamination and technological analyses.

The feasibility analysis was performed according to Lee et al. (1981) at the beginning and at the end of fermentation of all tests. Colony counting by plating on Petrifilm system was held to check the contamination (3M do Brasil, 2014). Bacterial count occurred after forty-eight hours of inoculation at constant temperature of $35^{\circ} \mathrm{C}$, using as tool the magnifying glass (Nova optical Systems XTS -20, Zoom Stereo Microscope).

Analyses of sulfuric acid $\left[\mathrm{g}\left(\mathrm{H}_{2} \mathrm{SO}_{4}\right) \mathrm{L}^{-1}\right]$, Total Reducing Sugars (TRS) and Ethanol Content (\%) were performed in wine obtained, according to CTC (2005). The amount of ethanol produced $(\mathrm{mL})$ was calculated taking into account the production of $380 \mathrm{~mL}$ of wine (standardized for the three experiments) multiplied by the ethanol content obtained. To calculate fermentation efficiency (\%), ethanol produced was divided by ethanol content, according to Fernandes (2006).

For statistical analysis, variance by $\mathrm{F}$ test and comparison of means by Tukey test were performed, according to Banzato \& Kronka (2006).

\section{Results and discussions}

Mash of the three experiments were standardized (Table 1) in five test days (blocks) of each study, with the amount of soluble solids ranging from 14 to 14.5 Brix. Addition of sulfuric acid was performed for lowering the $\mathrm{pH}$ to 4.5 in order to favor yeast comparing to bacteria in sugar consumption of mash.

Table 1 - Means and mean standard error for original ${ }^{\circ}$ Brix of used raw material (juice or molasses), ${ }^{\circ}$ Brix of the mash, mash $\mathrm{pH}$ without correction, corrected $\mathrm{pH}$, acidity and total reducing sugars (TRS) of the mash prepared for the three experiments: sugarcane juice, molasses 1 and molasses 2.

\begin{tabular}{lccc}
\hline Analysis & Sugarcane Juice & Molasses 1 & Molasses 2 \\
\hline Original ${ }^{\circ}$ Brix & $17.76 \pm 0.89$ & $85.00 \pm 0.00$ & $82.50 \pm 0.00$ \\
oBrix of the mash & $14.16 \pm 0.08$ & $14.08 \pm 0.04$ & $14.50 \pm 0.06$ \\
Mash pH without correction & $5.27 \pm 0.13$ & $5.40 \pm 0.05$ & $5.46 \pm 0.04$ \\
Corrected pH & $4.51 \pm 0.01$ & $4.50 \pm 0.00$ & $4.50 \pm 0.00$ \\
Acidity $\left[\mathrm{g}\left(\mathrm{H}_{2} \mathrm{SO}_{4}\right) \mathrm{L}^{-1}\right]$ & $1.02 \pm 0.09$ & $3.08 \pm 0.15$ & $3.63 \pm 0.18$ \\
TRS $(\%)$ & $13.12 \pm 0.23$ & $11.43 \pm 0.36$ & $11.76 \pm 0.33$ \\
\hline
\end{tabular}

High acidity values were found in mash of juice (Table 1), above $0.8 \mathrm{~g}\left(\mathrm{H}_{2} \mathrm{SO}_{4}\right) \mathrm{L}^{-1}$, which may be indicative of bacterial contamination (Ravaneli et al., 2006). The presence of high levels of contamination in the mash prepared with juice was beneficial, as it was possible to apply and verify the performance of biocides in the worst process conditions. The same can be observed for the mash prepared with molasses,

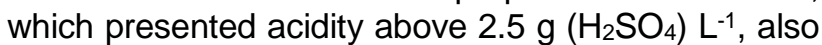
indicating possible high level of contamination.

Total reducing sugars (TRS) values for juice and molasses are within what is commonly found (Souza et al., 2005; Ravaneli et al., 2006), being the value of juice TRS concentration higher than two types 
of molasses. This by-product is exhausted in the sugar production process by nutrient removal during juice treatment and by removal of sucrose crystals in sugar production. No nutrient correction was performed in molasses in order to better observe the effect of antimicrobials.

The results presented below are only of those that showed significant difference for $\mathrm{F}$ and Tukey test.

\section{Antimicrobial action of Oregano Essential Oil}

For the used treatments, soluble solids found in wine were not significant $(F=0.1593 ; P \geq 0.05)$ for the mash made from sugarcane juice. However, there was significant difference for molasses in the two harvests, which showed lower soluble solids concentrations for OEO when compared to the control (Figure 1). The smallest amount of this parameter could be a sign ethanol production increase, as more sugars could have been converted into ethanol. However, the amounts of residual total reducing sugars (RTRS) and ethanol produced were not significantly different between the OEO and control treatment for both tests with molasses.
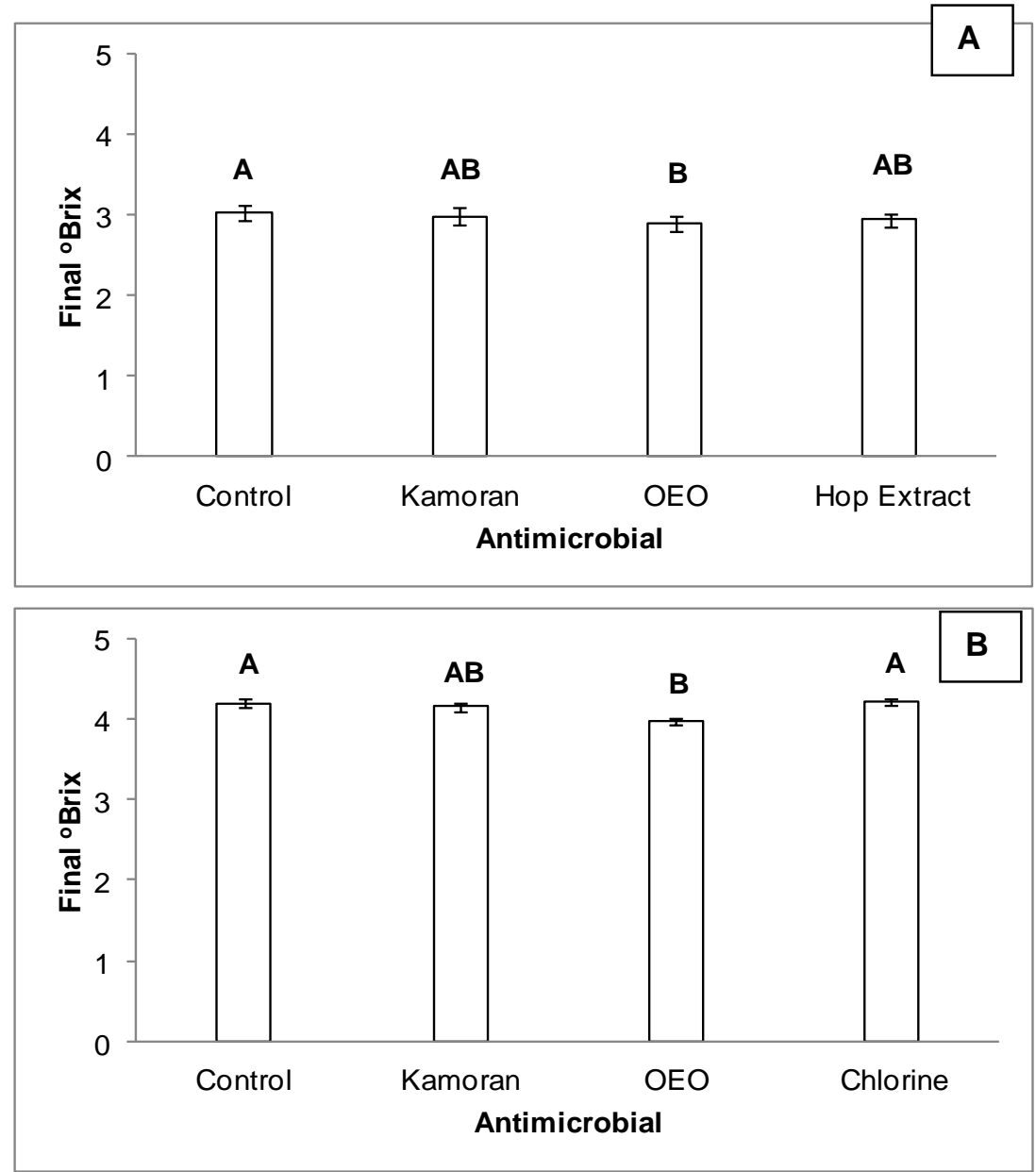

Figure 1 - Means and mean standard error for ${ }^{\circ}$ Brix of wine obtained after fermentation of mash of molasses with different antimicrobial treatments. A - 2012/2013 harvest and B - 2013/2014 harvest. Same letters do not differ by Tukey Test $(\mathrm{P} \leq 0.05)$.

Fermentation time was appropriate for all tests, being faster for the mash of sugarcane juice, which lasted $7 \mathrm{~h} 40 \mathrm{~min}$, while for the mash of molasses it had an average duration of 8 hours. In the Figure $1 \mathrm{~B}$, it is possible to observe that the final oBrix of fermentation performed in 2013/2014 harvest was slightly higher than in the previous harvest. Probably, the molasses used had more non-fermentable sugars.

Regarding the control of contaminants, we doubled the concentration of oregano oil of the test with mash of molasses from 2012/2013 harvest to
$2013 / 2014$, to try to find the appropriate dosage, since OEO has been promising in bacterial control in other processes, as pointed out by the study of Silva (2010). However, OEO continued to show little antimicrobial activity. Nevertheless, visually, it was observed that there was a significant foam reduction during the fermentation process in all tests (Figures 2 to 4), indicating that OEO may have antifoaming and/or dispersant action, requiring further studies with tests to confirm this effect. 


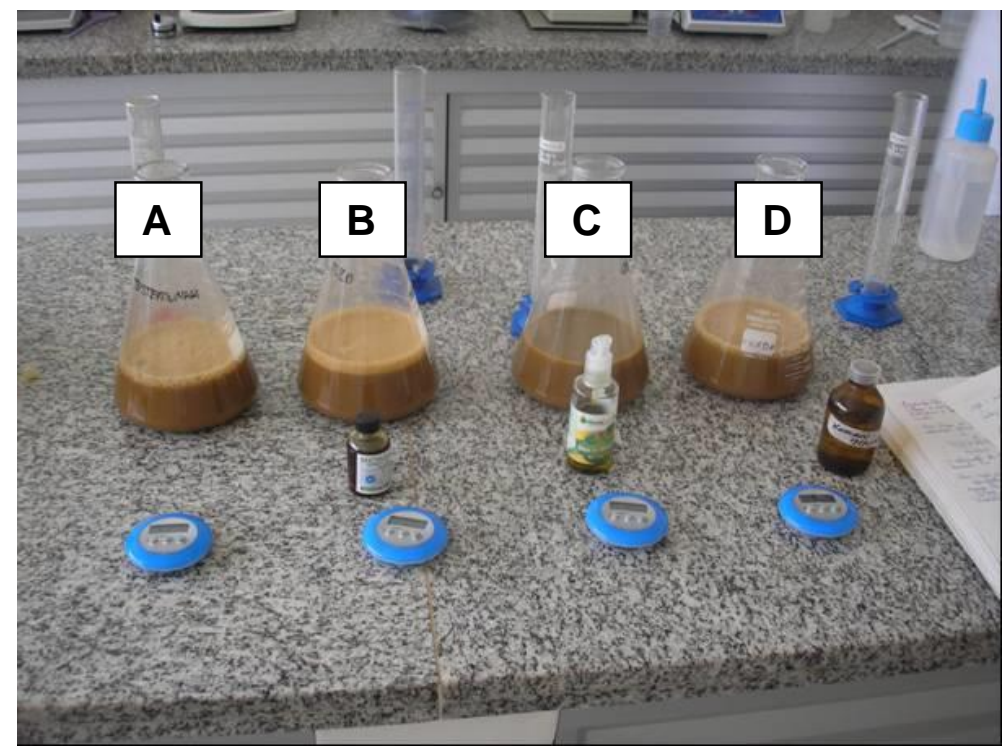

Figure 2 - Effects of antimicrobial treatments in foam formation in mash of sugarcane juice from 2012/2013 harvest. A: control; B: Hop extract; C: OEO and D: Kamoran®.

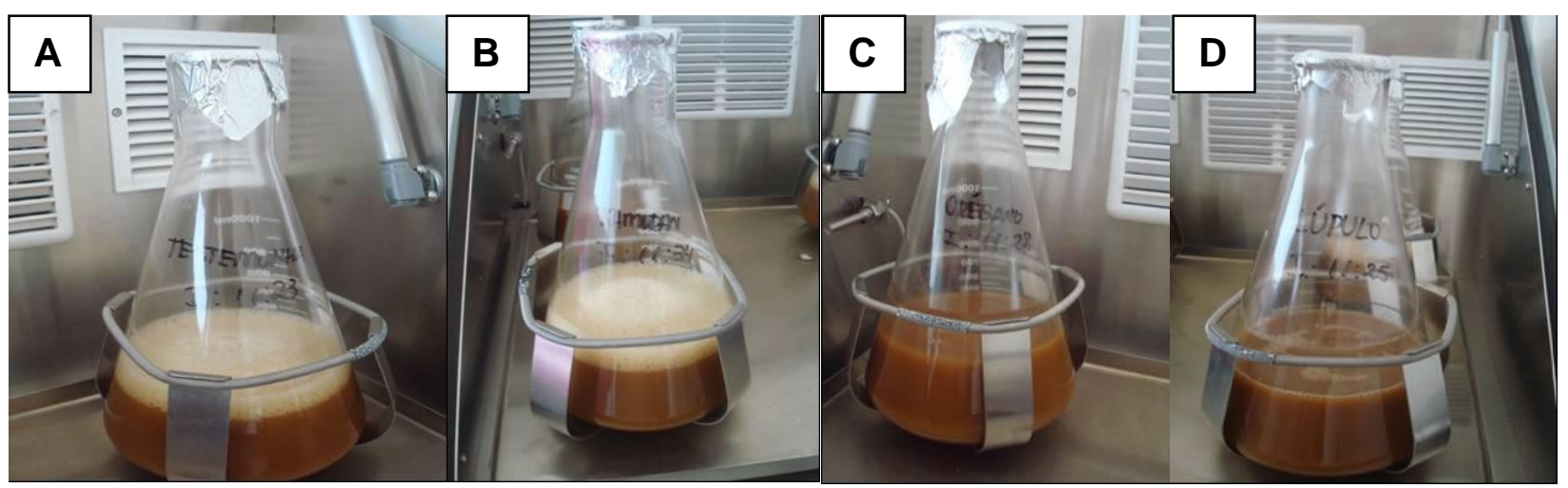

Figure 3 - Effects of antimicrobial treatments in foam formation in mash of molasses from 2012/2013 harvest. A: control; B: Kamoran $\AA$; C: OEO and D: Hop extract.

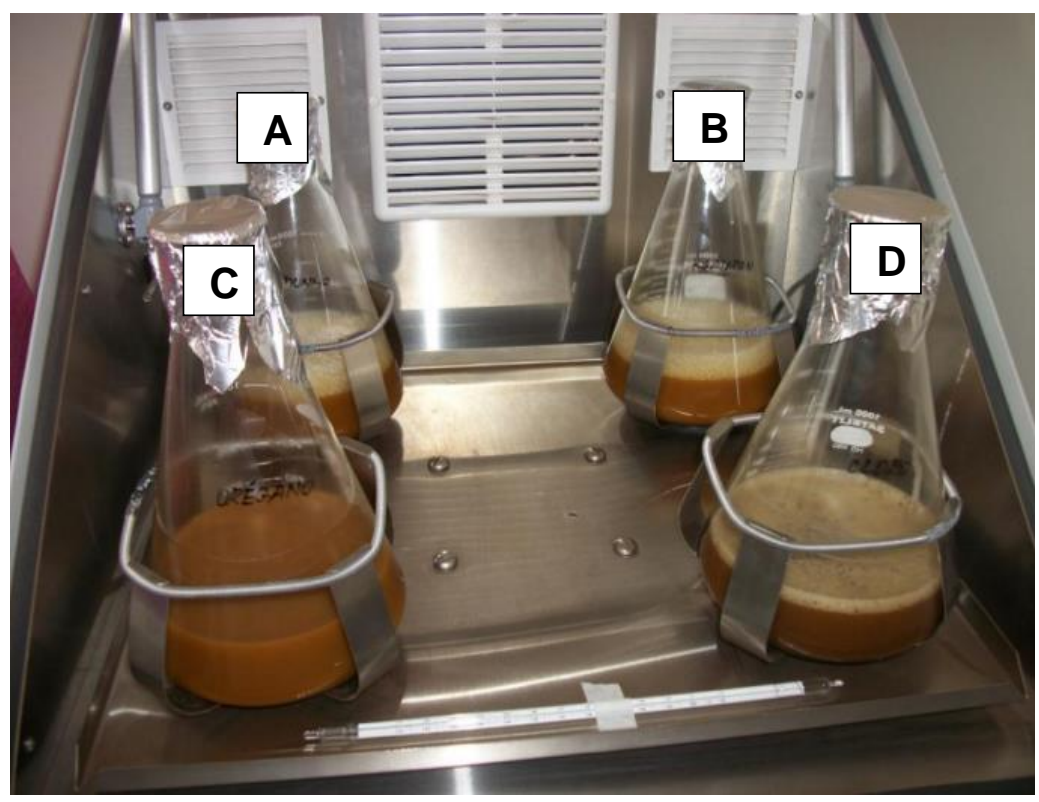

Figure 4 - Effects of antimicrobial treatments in foam formation in mash of molasses from 2013/2014 harvest. A: control; B: Kamoran®; C: OEO and D: Chlorine. 


\section{Antimicrobial effect of hop extract}

Final acidity (wine) showed significant difference only for the experiment with molasses from 2012/2013 harvest (Figure 5), and hop extract showed lower acidity than Kamoran ${ }^{\circledR}$ treatment. Lower concentration of acids indicates that contamination decreased in this treatment, which was confirmed with the reduction of final contamination (Figure $6 \mathrm{~B}$ ). In this study, Kamoran $\AA$, used as positive control, was not efficient in bacterial control, indicating that the dosage used in the study was not enough to contain contamination comparing to the other treatments.

Final contamination was lower for the treatment using hop extract either for mash of sugarcane juice or for molasses (Figure 6A), indicating that it is an important agent in the bacteria control, as observed and used for beer production (Caetano \& Madaleno, 2011).

Low contamination is important because, in ethanol production in Brazilian sugar mills, yeast is reused and decreasing bacterial concentration during fermentation allows obtain healthier yeasts, which can possibly increase ethanol production. With only one fermentation cycle, it was not possible to identify the beneficial effects of hop extract in the fermentation efficiency (mash of juice $F=0.4856$; $P \geq 0.05$ and mash of molasses 2012/2013 harvest $\mathrm{F}=3.1302 ; \mathrm{P} \geq 0.05$ ). However, studies with more cycles could show higher ethanol production, using hop extract as an antimicrobial agent.

In the third experiment, we decided to replace hop extract by chlorine dioxide, and evaluate the efficiency as contaminant control agent. However, despite showing positive results in means compared to the control treatment, it was not significant for final contamination $(F=0.1071 ; P \geq 0.05)$.

\section{Effect of antimicrobials on yeast viability}

Initial and final yeast viability did not change significantly in any of the tests (Table 2 and 3), indicating that treatments used at recommended dosages do not eliminate yeast cells from fermentation process.

In the first two tests, there was temperature control at $36{ }^{\circ} \mathrm{C}$, which is high compared to what is recommended for fermentation, which is $32^{\circ} \mathrm{C}$ (DellaBianca et al., 2013). This simulation was done purposefully, since they are conditions that stimulate the proliferation of bacteria. However, high temperature decreases yeast cell viability, as observed with mash of molasses from 2012/2013 harvest. So, for the $2013 / 2014$ harvest, the correct conduction temperature $\left(32^{\circ} \mathrm{C}\right)$ was used, what helped cell viability to be around $85 \%$, which is the recommended one (Ravaneli et al., 2011). Even at high temperature, mash of sugarcane juice showed appropriate initial and final viability (Table 2).

\section{Possibility of antimicrobial use during the fermentation process}

The use of antimicrobials during the fermentation process showed promising results, especially regarding the use of hop extract. However, more studies should be conducted to verify dosages that can further enhance contaminant control. OEO should be better investigated regarding the antifoaming and/or dispersant action. Foam formation in the fermentation step is common and may directly affect the process yield, especially with the release of $\mathrm{CO}_{2}$, which contributes to this phenomenon. Foam excess could cause vat spill. However, these losses can be controlled through the application of antifoamers and dispersants (Venturelli, 2008).

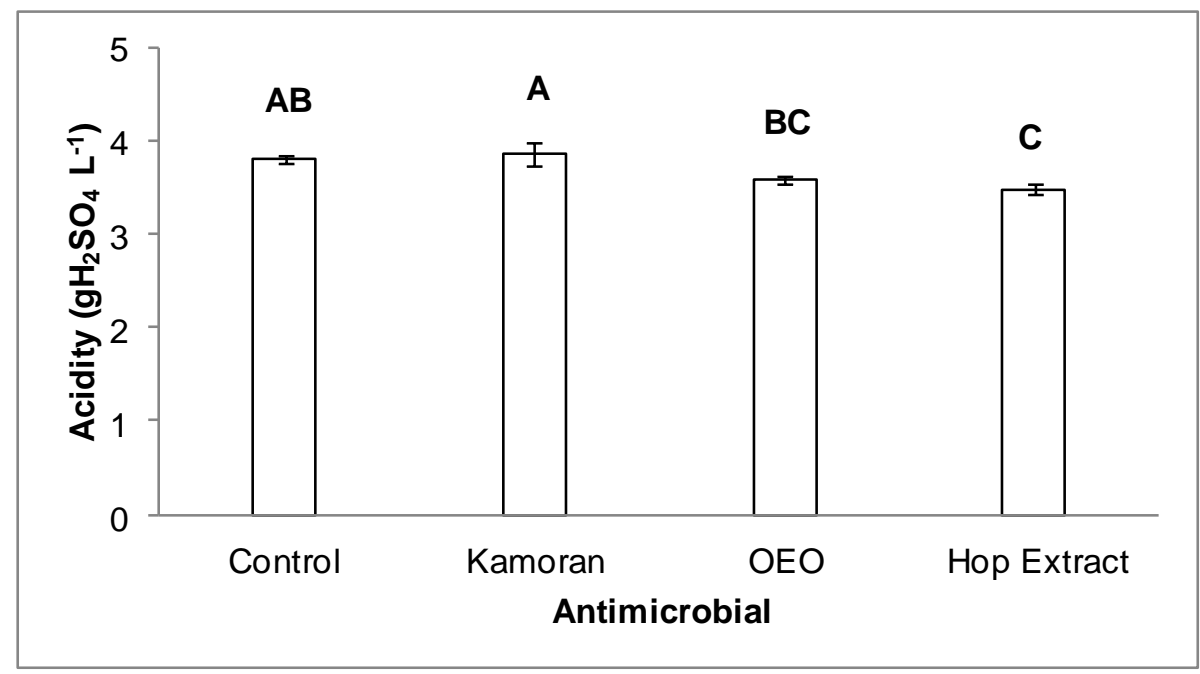

Figure 5 - Means and mean standard error for Acidity $\left[g\left(\mathrm{H}_{2} \mathrm{SO}_{4}\right) \mathrm{L}^{-1}\right.$ ] of wine obtained after fermentation of mash of molasses with different antimicrobial treatments, 2012/2013 harvest. Same letters do not differ by

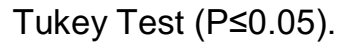



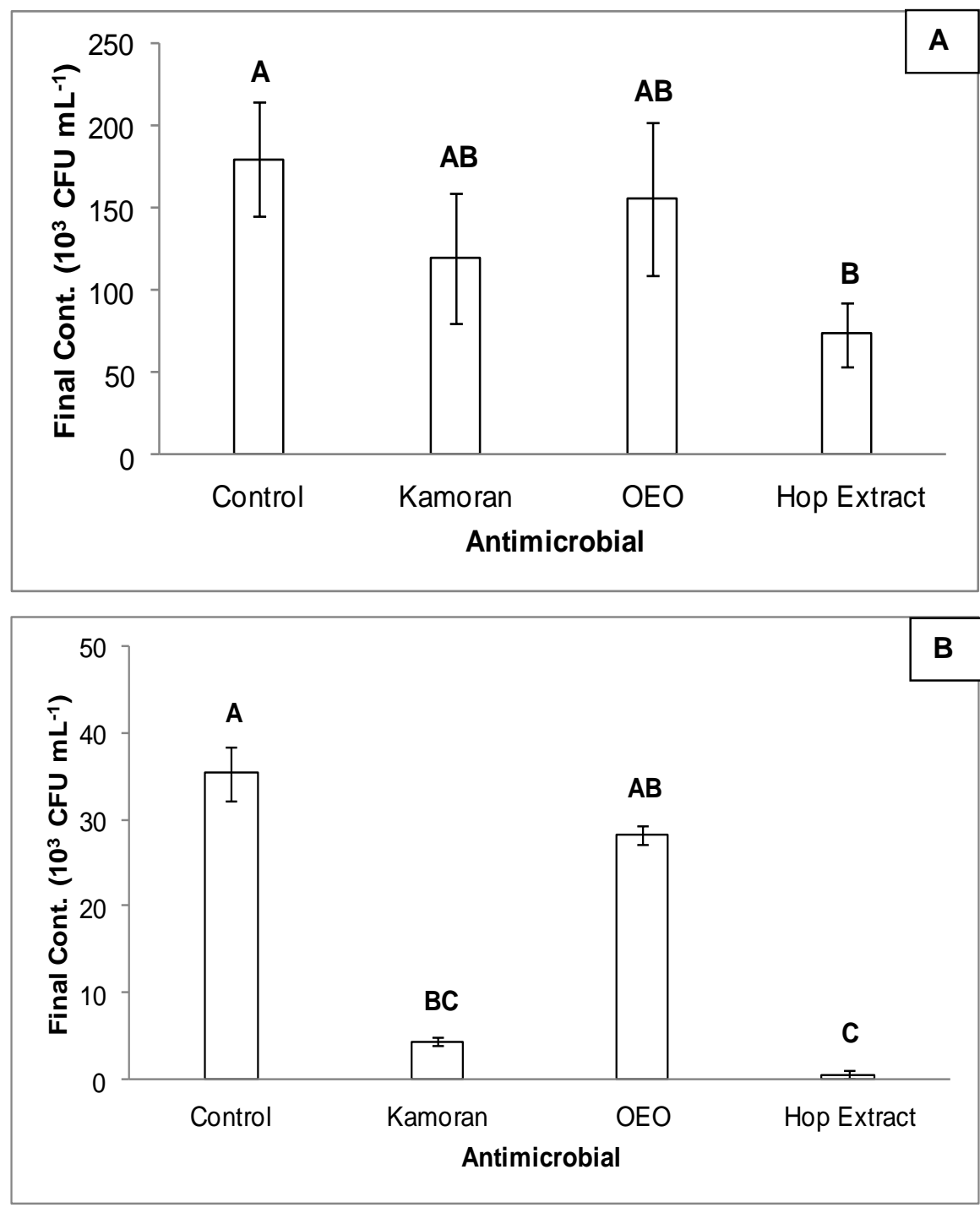

Figure 6 - Means and mean standard error for final contamination $\left(10^{3} \mathrm{CFU} \mathrm{mL} \mathrm{L}^{-1}\right)$ of fermentation with different antimicrobial treatments. A: Mash of sugarcane juice, 2012/2013 harvest and B: Mash of molasses, 2012/2013

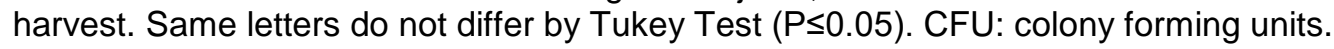

Table 2 - Means and mean standard error for Initial Viability (\%), Final Viability (\%) for antimicrobial treatments applied at the beginning of the fermentation process of the mash of sugarcane juice and molasses, 2012/2013 harvest.

\begin{tabular}{|c|c|c|c|c|}
\hline \multirow{2}{*}{ Causes of variation } & Initial Viability (\%) & Final Viability (\%) & Initial Viability (\%) & Final Viability (\%) \\
\hline & \multicolumn{2}{|c|}{ Sugarcane Juice } & \multicolumn{2}{|c|}{ Molasses } \\
\hline Treatments (F) & $1.5273 \mathrm{~ns}$ & $0.3999 \mathrm{~ns}$ & $1.3573 \mathrm{~ns}$ & 0.9983 ns \\
\hline Control & $89.18 \pm 2.39 \mathrm{~A}$ & $81.87 \pm 6.54 \mathrm{~A}$ & $77.17 \pm 7.65 \mathrm{~A}$ & $79.53 \pm 5.25 \mathrm{~A}$ \\
\hline Kamoran & $86.25 \pm 3.02 \mathrm{~A}$ & $84.37 \pm 3.81 \mathrm{~A}$ & $79.79 \pm 4.46 \mathrm{~A}$ & $69.06 \pm 9.27 \mathrm{~A}$ \\
\hline Oregano & $91.93 \pm 1.11 \mathrm{~A}$ & $84.04 \pm 5.59 \mathrm{~A}$ & $77.56 \pm 10.74 \mathrm{~A}$ & $82.44 \pm 6.03 \mathrm{~A}$ \\
\hline Hop & $90.17 \pm 2.51 \mathrm{~A}$ & $81.51 \pm 9.44 \mathrm{~A}$ & $88.00 \pm 3.71 \mathrm{~A}$ & $78.42 \pm 5.29 \mathrm{~A}$ \\
\hline Blocks (F) & 1.8480 ns & $23.4336^{* *}$ & $5.8542^{* *}$ & $1.2465 \mathrm{~ns}$ \\
\hline CV & 4.81 & 6.25 & 19.16 & 16.74 \\
\hline
\end{tabular}


Table 3 - Means and mean standard error for Initial Viability (\%), Final Viability (\%) for antimicrobial treatments applied at the beginning of the fermentation process of the mash of molasses, 2013/2014 harvest.

\begin{tabular}{lcc}
\hline Causes of variation & Initial Viability (\%) & Final Viability (\%) \\
\hline Treatments $(F)$ & $0.8910 \mathrm{~ns}$ & $0.2262 \mathrm{~ns}$ \\
\hline Control & $81.95 \pm 3.10 \mathrm{~A}$ & $82.53 \pm 4.92 \mathrm{~A}$ \\
Kamoran & $82.54 \pm 4.07 \mathrm{~A}$ & $85.81 \pm 4.39 \mathrm{~A}$ \\
Oregano & $85.82 \pm 2.87 \mathrm{~A}$ & $84.83 \pm 4.15 \mathrm{~A}$ \\
Chlorine & $83.56 \pm 2.61 \mathrm{~A}$ & $84.90 \pm 8.45 \mathrm{~A}$ \\
\hline Blocks $(\mathrm{F})$ & $7.0668^{* *}$ & $9.2319^{* *}$ \\
\hline CV & 4.83 & 7.78 \\
\hline
\end{tabular}

ns, ${ }^{*}$ and ${ }^{* *}=\mathrm{F}$ test non-significant at $5 \%$, significant at 5 and $1 \%$ probability, respectively. Same letters do not differ by Tukey Test $(\mathrm{P} \leq 0.05)$.

Emulsions of mineral oils and silanized silica are used as antifoamers, and the main oils are polyethers and silicones (Junker, 2007). With the opening of the international market for ethanol, producers of antifoamers seek biodegradable alternatives not to leave traces in the final product and residues of ethanol production as stillage (Venturelli, 2008).

For chlorine dioxide, new dosages should be tested, since it showed efficient means, however, with the statistical test employed, there was no difference comparing to the control treatment. The amount of fermentation cycles in further studies should be increased so that the effects of ethanol production efficiency during the fermentation process can be observed.

The dosage of Kamoran ${ }^{\circledR}$ should be increased, since in this study the antibiotic was used as positive effect to compare with biocides. However, it often showed to be very similar to the control treatment itself, with high contamination (Figure 6A) and acidity of the wine (Figure 5). This result corroborates information of Brazilian sugar mills themselves that report difficulty in controlling contamination with the dosage of $3 \mathrm{mg} \mathrm{L}^{-1}$. As it is a commonly used antibiotic, it can be said that possibly there is resistance to the active ingredient, formulated from monensin (Oliveira et al., 1996).

\section{Conclusions}

OEO has no antimicrobial effect in fermentation, on the other hand, it has properties that can be antifoaming and/or dispersant.

Hop extract reduces the final contamination of the fermentation of the mash of sugarcane juice or molasses.

The antimicrobial treatments used do not reduce the viability of yeast cells.

The use of antimicrobials during the fermentation process is promising.

\section{References}

3M do Brasil (2014) Placa $3 \mathrm{M}^{\mathrm{TM}}$ Petrifilm $^{\mathrm{TM}}$ para contagem de aeróbios. Disponível em: <http://solutions.3m.com.br/wps/portal/3M/pt_BR/Micr obiology/FoodSafety/productinformation/ >. (Acesso em: 22 nov. 2014).

Banzatto DA, Kronka SN (2006) Experimentação Agrícola. 3. Ed. Funep. Jaboticabal. 237p.

Basso LC, Basso TO, Rocha SN (2014) Ethanol Production in Brazil: The Industrial Process and Its Impact on Yeast Fermentation. Disponível em: <http://cdn.intechopen.com/pdfs-wm/20058.pdf>.

(Acesso em: 17 mar. 2014).

Caetano ACG, Madaleno LL (2011) Controle de contaminantes bacterianos na fermentação alcoólica com a aplicação de biocidas naturais. Ciência \& Tecnologia Fatec-JB 2(1):27-37.

Chum HL, Warner E, Seabra JEA, Macedo IC (2014) A comparison of commercial ethanol production systems from Brazilian sugarcane and US corn. Biofuels, Bioproducts and Biorefining 97:979-991.

Dashko S, Zhou N, Campagno C, Piskur J (2014) Why, when and how did yeast evolve alcoholic fermentation? FEMS Yeast Research 14:826-832.

Della-Bianca BE, Basso TO, Stambuk BU, Basso LC, Gombert AK (2013) What do we know about the yeast strains from the Brazilian fuel ethanol industry? Applied Microbiology and Biotechnology 8:205-223.

CTC (2005) Manual de métodos de análises para açúcar. 1th ed., CTC: Piracicaba.

Fernandes AC (2006) Cálculos na agroindústria da cana-de-açúcar, $2^{\mathrm{a}}$ ed. Piracicaba. $240 \mathrm{p}$.

Junker B (2007) Foam and its mitigation in fermentation systems. Biotechnology Progress 23:767-784. 
Lapoli FR, Hassemer MEN, Camargo JG, Damasio DL, Recio MAL (2005) Desinfecção de Eficientes Sanitários através de Dióxido de cloro. Engenharia Sanitária Ambiental 10(3):200-208.

Lane JH, Eynon L (1934) Determination of reducing sugars by Fehling solution with methylene blue indicator. Norman Rodger. London. 8p.

Lee SS, Robinson FM, Wong HY (1981) Rapid determination of yeast viability. Biotechnology Bioengineering Symposium, n. 11.

Leite IJ, Faria JR, Marquez LDS, Resende MM, Ribeiro EJ, Cardoso VL (2013) Evaluation of hop extract as a natural antibacterial agent in contaminated fuel ethanol fermentations. Fuel Processing Technology 106: 611-618.

Mundo dos Óleos (2014) Óleo de orégano. Disponível em: http://www.mundodosoleos.com/oleos-funcionais/oleo-de-oregano. (Acesso em: 23 nov. 2014).

Muthaiyan A, Limayem A, Ricke SC (2011) Antimicrobial strategies for limiting bacterial contaminants in fuel bioethanol fermentations. Progress in Energy and Combustion 37(3):351-370.

Naturoils (2014). Oleos Essencias: Oleo Essencial de Oregano. Disponivel em:

$<$ http://www.naturoils.com.br/\#!óleos-

essenciais/vstc2=oregano $>$. (Acesso em: 02 nov. 2014).

Oliveira AJ, Gallo CR, Alcarde VE, Godoy A, Amorim HV (1996) Métodos para o controle microbiológico na produção de açúcar e álcool. Piracicaba: FERMENTEC/FEALQ/ESALQ, 89p.

Oliveira JA, Garbin JR, Câmara C, Frigieri MC, Madaleno LL (2013) Radiação Ultravioleta no controle dos micro-organismos na água de diluição e no mosto de melaço. STAB: açúcar, álcool e subprodutos 32(1):49- 53 .
Olmstead J (2012) Bugs in the System: How the FDA fails to regulate antibiotics in ethanol production. Institute for Agriculture and Trade Policy, may, 2012. Disponível em: <http://www.iatp.org/files/2012_05_02_AntibioticsInEt hanol_JO_0.pdf>. (Acesso em: 17 mar. 2014).

Quimica Real (2014) Produtos. Belo Horizonte, 2012. Disponivel em: http://www.quimicareal.com.br. (Acesso em: 05 nov. 2014).

Ravaneli GC, Madaleno LL, Presotti LE, Mutton MA, Mutton MJR (2006) Spittlebug infestation in sugarcane affects ethanolic fermentation. Scientia Agricola 63(6):543-546.

Ravaneli GC, Garcia DB, Madaleno LL, Mutton MA, Stupiello JP, Mutton MJR (2011) Spitlebug impacts on sugarcane quality and ethanol production. Pesquisa Agropecuária Brasileira 46:120-129.

Skinner-Neme KA, Nichols NN, Leathers TD (2007) Biofilm formation by bacterial contaminants of fuel ethanol production. Biotechnology Letters 29:379-383.

Silva JPL, Duarte-Almeida JM, Perez DV, Franco BDGM (2010) Óleo essencial de orégano: interferência da composição química na atividade frente a Salmonella enteritidis. Ciência e Tecnologia de Alimentos 30:136-141.

Souza ZM, Paixão ACS, Prado RM, Cesarin LG, Souza SR (2005) Manejo de palhada de cana colhida sem queima, produtividade do canavial e qualidade do caldo. Ciência Rural 35(5):1062-1068.

Venturelli WH (2008) Estudo da atividade antiespumante de ésteres etílicos derivados de óleos vegetais. 2008.69f. Dissertação (Mestrado). Faculdade de Filosofia, Ciências e Letras de Ribeirão Preto, Universidade de São Paulo, Ribeirão Preto. 